\title{
Effects of Annona muricate Extract on Short Chain Fatty Acid Level of Colorectal Cancer Patients
}

\author{
Lili Indrawati, ${ }^{1}$ Purwantyastuti, ${ }^{2}$ Murdani Abdullah, ${ }^{3}$ Ingrid S Surono ${ }^{4}$ \\ ${ }^{1}$ Department of Pharmacology and Therapy Faculty of Medicine Universitas Kristen \\ Indonesia Jakarta \\ ${ }^{2}$ Department of Pharmacology Faculty of Medicine Universitas Indonesia/Dr. Cipto \\ Mangunkusumo General National Hospital Jakarta \\ ${ }^{3}$ Division of Gastroenterology Department of Internal Medicine Faculty of Medicine \\ Universitas Indonesia/Dr. Cipto Mangunkusumo General National Hospital Jakarta \\ ${ }^{4}$ Food Technology Department Faculty of Engineering Bina Nusantara University Jakarta
}

\begin{abstract}
Annona muricata leaves contains phytochemical substances, such as alkaloids, tannins, flavonoids, saponins, anthraquinones and cardiac glycosides, ellagic acid, triterpenoids, $\beta$ - sitosterol. Polyphenols are considered to be potential in providing health benefits via modulation the gut microecology. Alteration of the gut microbiota composition can be achieved by consuming of flavonol-rich foods that exerting prebiotic-like effects. Short chain fatty acids (SCFA) that are produced from highly fermentable fibers is considered to be protective against colon cancer. Subjects were assigned consecutively into two group: ethanolic extract of A. muricata, and maltose as placebo. Ssupplementation was conducted for 8 weeks in a capsule. SCFA level assessment was conducted at baseline and the end of the study period. Gas liquid chromatography was used to determine concentration of butyrate. Fiber intake was measured using food record. Concentrations of fecal butyrate levelwas not significantly different between Fraction of A. muricata water extract that is soluble in ethanol (FAMSE) and placebo $(\mathrm{p}=0.854)$. Level of others SCFA were also not significantly different. The low fiberintakeisconsistent with the finding on fecal butyrate concentration, as shown by no significant increase in both groups. There is no statistically significant effect of supplementation with ethanol-soluble fraction of $A$ muricata leaves water extract on fecal SCFA level of colo rectal cancer (CRC) patients, andin line with fiber intake below recommended daily allowance throughout the study period.
\end{abstract}

Keywords: phytochemical substances, fiber intake, gut microbiota

\section{Efek Ekstrak Annona muricate terhadap Kadar Asam Amino Rantai Pendek pada Pasien Kanker Kolorektal}

Daun sirsak (Annona muricata) mengandung senyawa fitokimia seperti alkaloid, tanin, flavonoid, saponin, antraquinon, cardiac glycosides, ellagic acid, triterpenoid, dan $\beta$-sitosterol. Polifenol memiliki potensi yang baik dalam kesehatan dengan cara memodulasi mikro-ekologi usus. Komposisi microbiota usus dapat berubah dengan cara mengkonsumsi makanan yang banyak mengandung flavonol yang memberikan efek seperti prebiotik. Asam lemak rantai pendek yang dihasilkan dari fermentasi tinggi serat dapat mencegah terjadinya kanker kolon. Subyek penelitian dibagi menjadi dua kelompok secara berurutan, yaitu ekstrak etanol Annonamuricata dan maltosa sebagai plasebo. Pemberian suplemen dilakukan selama 8 minggu dalam bentuk kapsul. Pengukuran kadar asam lemak rantai pendek dilakukan pada awal dan akhir masa studi ini. Pengukuran kadar asam butirat dilakukan dengan kromatografi gas. Asupan serat diukur berdasarkan catatan makanan. Konsentrasi kadar asam butirat pada feses tidak berbeda signifikan dengan fraksi ekstrak air Annona muricata yang larut di dalam etanol dan plasebo $(\mathrm{p}=0.854)$. Kadar dari asam lemak rantai pendek lainnya juga tidak berbeda nyata. Asupan serat yang rendah sejalan dengan pengukuran kadar asam butirat di feses yang menunjukkan tidak ada peningkatan secara signifikan pada kedua kelompok. Tidak terdapat pengaruh yang signifikan suplementasi dengan fraksi larut etanol ekstrak air daun Annona muricata pada konsentrasi asam lemak rantai pendek feses dari pasien kanker kolon dan hal itu sejalan dengan asupan serat dibawah rekomendasi harian yang dilakukan selama masa studi ini. 
Kata kunci: fitokimia, asupan serat, microbiota saluran cerna

*LI: Penulis Koresponden; E-mail: lili_zain@yahoo.com

\section{Background}

Annona muricata leaves contains phytochemical substances, such as alkaloids, tannins, favonoids, saponins, anthraquinones and cardiac glycosides, ellagic acid, triterpenoids, $\beta$ sistosterol. ${ }^{1-3}$ Several plant polyphenols may decrease the incidence of many types of cancers, especially in colon epithelia hence they may have chemoprevention property such as flavonoidquercetin and flavone (2-phenyl-4H-1-benzopyran-4-one). ${ }^{4}$

Polyphenols are also considered to be potential in providing health benefits via modulation the gut micro-ecology. Alteration of the gut microbiota composition can achieved by consuming of favonol-rich foods that exerting prebiotic-like effects. ${ }^{5}$ The extract of dried $A$. muricata leaves have been shown to exert antimicrobial or bacteriostatic activities towards some species of bacteria in agar plate such as Escherichia coli, Pseudomonas aeruginosa, Shigella flexneri. ${ }^{6}$ By definition, all dietary fibers comes relatively intact in the large intestine because it does not undergo digestion in the small intestine. The type of fiber and the colonic microbiota determine its metabolism. Short chain fatty acids (SCFA) that are produced from highly fermentable fibers is considered to be protective against colon cancer. ${ }^{7}$

\section{Materials and methods}

The subjects were CRC outpatient after undergoing tumor surgery at Rumah Sakit Umum Pusat Nasional Dr. Cipto Mangunkusumo (Dr. Cipto Mangunkusumo Hospital), Jakarta, Indonesia.

Approval of the study protocol was given by Committee of Medical Ethics, Faculty of Medicine, Universitas Indonesia (No. 406/H2.F1/ETIK/2013). The study protocol was also registered on ClinicalTrials.gov under the identifier NCT02439580. Subject participation was optional, and written informed consent was acquired before joining the study. The study was held from October 2013-June 2014.

The inclusion criteria are male and female CRC patients older than 30 years who had receiving tumor resection care, agree to take one capsule per day of $A$. muricate extract or a placebo as an additional treatment throughout the study period were enrolled in the study and having adequate hematological and biochemical parameters and a Karnofsky performance status of $\geq 60 \%$.

Patients with uncontrolled hypertension (untreated systolic blood pressure $>160 \mathrm{~mm} \mathrm{Hg}$, or diastolic blood pressure $>95 \mathrm{~mm} \mathrm{Hg}$ ); severe heart problems; upper limit of serum glutamic pyruvic transaminase (SGPT), serum glutamic oxaloacetic transaminase (SGOT), and creatinine are $111 \mathrm{U} / \mathrm{L}, 123 \mathrm{U} / \mathrm{L}, 3.6 \mathrm{mg} / \mathrm{dL}$ respectively; a disability causing them uncapable to communicate verbally; or a history of cancers other than colorectal (such as non-melanoma skin cancer, basal cell carcinoma, and squamous cell carcinoma) in the past five years, were excluded from the study. To avoid potentially conflicting conditions and treatments, patients withthe following conditions were also eliminated from the study: pregnant or lactating women, and those not using sufficient contraception, patients taking other-research's drugs, patients with hereditary non-polyposis colorectal cancer (HNPCC), and patients consuming probiotic supplementation during the study period.

\section{Annona muricata L. extract}


The A. muricata extract involved in this study is fraction of $A$. muricata water extract that is soluble in ethanol (FAMSE). FAMSE contains $0.36 \%$ acetogenin $(\mathrm{w} / \mathrm{w})$ or $3.6 \mathrm{mg} / \mathrm{g}$, and a $10 \mathrm{~g}$ water extract is equivalent to a $2 \mathrm{~g}$ ethanolic fraction. The study subjects consumed either $300 \mathrm{mg}$ of FAMSE or maltose as a placebo in the form of a capsule after breakfast.

\section{Procedures}

A randomized double-blind placebo-controlled trial (RCT) was performed. The patients were randomly allocated into either FAMSE or placebo, through block randomization (four patients per block), supplementation was given for eight weeks.

SCFA level assessments were conducted at baseline and the end of the study period. Gas liquid chromatography was used to determine concentration of butyrate. Fiber intake was measured using food record. Participants were asked to record their intake by weighing food consume using food scale. Estimated intakes of fiber was calculated on the basis of the average value of two-day food record.

\section{Results}

Concentrations of fecal butyrate level was not significantly different between FAMSE and placebo group at baseline (Table 1).

The intake of fiber in general is far from RDA based on age and gender, only at the baseline both groups showed higher percentage compared the subsequent measurements (Table 3). The low fiber intake is in consistent with the finding on fecal butyrate concentration, as shown by no significant increase in both groups (tabel 2). There is no significant correlation $(\mathrm{p}=0.235)$ between fiber intake and butyrate level.

Table 1. Concentrations of Fecal Butyrate of the Subjects at Baseline

\begin{tabular}{lccc}
\hline & \multicolumn{2}{c}{ Groups } & Between-group \\
\cline { 2 - 4 } & $\begin{array}{c}\text { FAMSE } \\
(\mathrm{n}=15)\end{array}$ & $\begin{array}{c}\text { Placebo } \\
(\mathrm{n}=15)\end{array}$ & $\begin{array}{c}\text { Berence p-value } \\
\text { differen }\end{array}$ \\
\hline Butyrate & $0.83(0.4-1.14)$ & $1.02(0.66-1.77)$ & 0.346 \\
Iso Butyrate & $4.01 \pm 3.23$ & $4.80 \pm 3.35$ & 0.533 \\
Valerate & $1.24(0.52-2.12)$ & $2.04 \pm 1.19$ & 0.175 \\
Iso Valerate & $3.82(2.06-6.45)$ & $5.28 \pm 3.10$ & 0.581 \\
\hline
\end{tabular}

*) Data are mean $\pm \mathrm{SD}$;) Independent sample t test was performed

Table 2. Fecal Short Chain Fatty Acid Analysis Between Groups

\begin{tabular}{|c|c|c|c|c|c|c|}
\hline & & $\begin{array}{l}\text { FAMSE } \\
n=14\end{array}$ & $\begin{array}{l}\text { Within } \\
\text { group } \\
\text { difference } \\
\mathrm{p} \text { value }\end{array}$ & $\begin{array}{l}\text { Placebo } \\
\mathrm{n}=14 \\
\text { Living Cells }(\%)\end{array}$ & $\begin{array}{l}\text { Within } \\
\text { group } \\
\text { difference } \\
\text { p value }\end{array}$ & $\begin{array}{l}\text { Between } \\
\text { group } \\
\text { difference } \\
\text { p value }\end{array}$ \\
\hline \multirow[t]{2}{*}{ Butyrate } & Before & $0.83(0.4-1.14)$ & 0.27 & $1.02(0.66-1.77)$ & 0.096 & 0.85 \\
\hline & After & $1.06(0.49-7.13)$ & & $1.26(0.91-9.91)$ & & \\
\hline \multirow{2}{*}{$\begin{array}{l}\text { Iso } \\
\text { Butyrate }\end{array}$} & Before & $4.01 \pm 3.23$ & 0.17 & $4.80 \pm 3.35$ & 0.37 & 0.96 \\
\hline & After & $3.14 \pm 2.64$ & & $3.98 \pm 2.55$ & & \\
\hline Valerate & $\begin{array}{l}\text { Before } \\
\text { After }\end{array}$ & $\begin{array}{l}1.24(0.52-2.12) \\
1.93 \pm 1.37\end{array}$ & 0.43 & $\begin{array}{l}2.04 \pm 1.19 \\
2.43 \pm 1.36\end{array}$ & 0.41 & 0.83 \\
\hline Isovalerate & $\begin{array}{l}\text { Before } \\
\text { After }\end{array}$ & $\begin{array}{l}3.82(2.06-6.45-) \\
2.58(1.26-5.32)\end{array}$ & 0.30 & $\begin{array}{l}5.28 \pm 3.10 \\
5.50(1.82-6.18)\end{array}$ & 0.40 & 0.87 \\
\hline
\end{tabular}

*) Data are mean \pm SD for normally distributed data; $\dagger$ ) median (25th, 75th percentiles) for non- normally distributed data

*) Independent sample $t$ test was conducted for normally distributed data, Mann-Whitney U test for nonnormally distributed data 
Table 3: Dietary Fiber Intake During Supplementation

\begin{tabular}{clllll}
\hline Dietary & $\begin{array}{l}\text { Supplement } \\
\mathrm{n}=15(\mathrm{n}, \%)\end{array}$ & $\begin{array}{l}\text { Within- } \\
\text { group } \\
\text { differenc } \\
\mathrm{e}\end{array}$ & $\begin{array}{l}\text { Placebo } \\
\mathrm{n}=15(\mathrm{n}, \%)\end{array}$ & $\begin{array}{l}\text { Within- } \\
\text { group } \\
\text { difference } \\
\text { p-value }\end{array}$ & $\begin{array}{l}\text { Between- } \\
\text { group } \\
\text { difference p- } \\
\text { value }\end{array}$ \\
\hline Fiber & & & & \\
\hline Week 2 & $12.15 \pm 5.82$ & 0.402 & $11.39 \pm 6.10$ & 0.777 & 0.739 \\
Week 4 & $9.50 \pm 5.31$ & & $12.36 \pm 8.08$ & & \\
Week 6 & $11.19 \pm 7.64$ & & $11.25 \pm 6.69$ & \\
Week 8 & $11.30 \pm 5.47$ & & $11.93 \pm 7.03$ & \\
Mean & $11.03 \pm 5.05$ & & $11.73 \pm 6.04$ & \\
\hline Percentage & & & & \\
from RDA & & & & \\
\hline Week 2 & $39.58 \pm 20.57$ & 0.437 & $36.24 \pm 19.74$ & 0.714 & \\
Week 4 & $31.34 \pm 19.81$ & & $40.57 \pm 30.72$ & \\
Week 6 & $36.79 \pm 26.27$ & & $36.54 \pm 24.57$ & \\
Week 8 & $36.63 \pm 19.02$ & & $38.76 \pm 24.71$ & & \\
Mean & $36.08 \pm 18.53$ & & $38.03 \pm 22.51$ & & \\
\hline
\end{tabular}

\section{Discussion}

Supplementation of FAMSE did not show significant change on fecal butyrate level of the subjects. The fiber intake of the subjects of both groups during the study period are below the daily recommended intake for each age groups. Low fermentable fibers resulted in lack of short chain fatty acids including butyrate.

Those SCFA, particularly butyrate, demonstrate to have their potential in preventing growth and inducing apoptosis in colon cancer cells. Therefore, they are known to play role on secondary chemoprevention. SCFA can also activate different drug metabolising enzymes hence decrease the level of carcinogens. This can reduce the number of mutations and cancer risk. Consequences of the typical expression patterns stimulated by butyrate considering normal and tumour cells are still unclear.

Glutathione-S-transferase (GSTs) activate some substrates (halogenated compounds) rather than deactivate them. GSTs are biotransformation enzymes to remove many carcinogens. In tumour-derived cell lines, such enzyme systems enhanced in cellular levels to protect against foodderived genotoxic compounds such as 4-hydroxynonenal (HNE). Because of GSTs' capability in detoxifying endogenous and exogenous (food- or smoking-derived) carcinogens like HNE or benzo(a)pyrene, similar mechanisms occurring in non-transformed cells may very well reduce cancer initiation. Thus, those mechanisms are thought to be an effective means of primary cancer chemoprevention. GST induction could theoretically increase the survival of transformed cells in tumour and in adenoma cells $(8)$.

There is strong association between increased intake of dietary fiber with lower CRP concentrations. Maet al. suggests that a diet high in fiber may contribute in lowering inflammation. Total dietary fiber, soluble fiber, insoluble fiber are negatively associated with CRP concentrations. The mechanism between dietary fiber and inflammation is still not fully understood. It is indicated that dietary fiber reduces inflammation by reducing lipid oxidation. Normal bowel microbiota also helps to prevent inflammation by providing a healthy intestinal environment (9).

Colon cancer cell proliferation and apoptosis activation were decreased bybutyrate capacity in inhibiting miR-92a transcription. These actions preceded by reduction of c-Myc and enhancement of p57 levels. There is substantial experimental evidence that butyrate is unique among the major products of saccharolytic fermentation. There is substantial experimental evidence that butyrate is unique among the major products of saccharolytic 
fermentation, in its colonic mucosa preservation. First, colonocytes gain energy from it. Second, it has many different types of antineoplastic properties, demonstrated by its action as a histone deacetylase inhibitor, it down-regulates the key canonical Wnt- signaling pathway related to colonic carcinogenesis, and diminishes carcinogens load, such as bile acids and red meat products (11). Although inconclusive, epidemiological studies show an inverse relationship between the intake of dietary fiber and incidence of colon cancer, hence increased colonic SCFAs as a result of fiber fermentation may be responsible for the protective effect (12).

Further extensive studies are also necessary to explore the relationship between carbohydrate, resistant starch, and fibers intake, as well as gut microbiota, butyrate, with apoptosis, inflammatory response and cancer protection, and to study the mechanism involved in those relationships. Suggestion for traditional diet of Asian rich in vitamin, minerals, dietary fibers, resistant starch, protein but low fat as well as sugars for CRC patients and also healthy people to prevent CRC are urgently highlighted.

\section{Conclusion}

There is no statistically significant effect of supplementation with Fraction of A. muricata leaves water extractthat'ssoluble in ethanol (FAMSE) on fecal SCFA level of CRC patients, andin line with fiber intake below recommended daily allowance throughout the study period

\section{Author disclosures}

The authors have no conflicts of interest or financial ties to disclose in this work.

\section{References}

1. Ezirim AU, Okachi VI, James AB, Adebeshi OA, Ogunnowo S, Odeghe O. Induction of apoptosis in myelogenous leukemic K562 cells by ethanolic leaf extract of Annona muricata. Global J Res Med Plants \&Indigen Med. 2013;2(3):142-51.

2. Marino $\mathrm{DC}^{1}$, Sabino LZ, Armando J Jr, Ruggiero Ade A, Moya HD. Analysis of the polyphenols content in medicinal plants based on the reduction of cu(ii)/bicinchoninic complexes. J Agric Food Chem. 2009 Dec 9;57(23):11061-6. doi: 10.1021/jf902197p.

3. Adewole SO, Ojewole JA. Protective effects of Annona muricata Linn. (Annonaceae) leaf aqueous extract on serum lipid profiles and oxidative stress in hepatocytes of streptozotocin-treated diabetic rats. Afr J Tradit Complement Altern Med. 2008;6(1):30-41.

4. Psahoulia FH, Drosopoulos KG, Doubravska L, Andera L, Pintzas A. Quercetin enhances TRAILmediated apoptosis in colon cancer cells by inducing the accumulation of death receptors in lipid rafts. Mol Cancer Ther. 2007;6(9):2591-9.

5. Laparra JM, Sanz Y. Interactions of gut microbiota with functional food components and nutraceuticals. Pharmacol Res. 2010 Mar;61(3):219-25. doi: 10.1016/j.phrs.2009.11.001

6. Ross IA. Medicinal Plants of the World Volume 1Chemical Constituents, Traditional and Modem Medicinal Uses. $2^{\text {nd }}$ ed. New York: Springer Science + Business Media; 2003.

7. Lupton JR. Microbial degradation products influence colon cancer risk: the butyrate controversy. $J$ Nutr. 2004 Feb;134(2):479-82.

8. Scharlau D, Borowicki A, Habermann N, Hofmann T, Klenow S, Miene C, et al. Mechanisms of primary cancer prevention by butyrate and other products formed during gut flora-mediated fermentation of dietary fibre. Mutat Res. 2009 Jul-Aug;682(1):39-53. doi: 10.1016/j.mrrev.2009.04.001. Epub 2009 Apr 19.

9. Ma Y, Griffith JA, Chasan-Taber L, Olendzki BC, Jackson E, Stanek EJ, et al. Association between dietary fiber and serum C-reactive protein. Am J Clin Nutr. 2006 Apr; 83(4): 760-766.

10. Hu S, Liu L, Chang EB, Wang JY, Raufman JP. Butyrate inhibits pro-proliferative miR-92a by diminishing c-Myc-induced miR-17-92a cluster transcription in human colon cancer cells. Mol Cancer. 2015 Oct 13;14:180. doi: 10.1186/s12943-015-0450-x.

11. O'Keefe SJ, Li JV, Lahti L, Ou J, Carbonero F, Mohammed K, et al. Fat, Fibre and Cancer Risk in African Americans and Rural Africans. Nat Commun. 2015 Apr 28;6:6342. doi: 10.1038/ncomms7342.

12. Zhang LS, Davies SS. Microbial metabolism of dietary components to bioactive metabolites: opportunities for new therapeutic interventions. Genome Med. 2016; 8: 46. 